Society for the Anthropology of Work • Policing and Labor

\title{
The Politics of \\ Respectability: Race, \\ Policing, and Occupational \\ Identity in Atlanta
}

Tatenda Mangurenje

Published on: Dec 04, 2020

DOI: $10.21428 / 1 \mathrm{~d} 6 \mathrm{be} 30 \mathrm{e} .211 \mathrm{~b} 8 \mathrm{dc} 3$

License: Creative Commons Attribution 4.0 International License (CC-BY 4.0). 
Since 2014, we have witnessed a cascade of video recordings showing African Americans dying during police contact. Although police violence had always been a feature of the American psyche, particularly among racial and ethnic minorities, video evidence of Michael Brown's death and the Black Lives Matter protests that ensued raised the public's consciousness about the issue of police violence (Rickford 2015), leading up to the 2020 protests and riots in response to the deaths of George Floyd and Breonna Taylor.

As discourse surrounding police violence extends beyond African American academic and activist circles (Hall 1978; Shakur 1987; Bell 1992; Jackson 1994), one key feature has remained salient to the construction of the relationship between race and policing. Discussions regarding police brutality largely cast officers as white subjects who, whether implicitly or explicitly, are depicted as the violent embodiment of white authority, while the victims of police violence are African Americans (Rickford 2015; Ritskes 2015).

But as we think through the implications of this racialization, how do we situate the thousands of African American police officers around the United States? The categorization of police as white subjects contradicts demographic shifts in urban police departments, which have seen an increase in diversity over the last few decades as departments in major cities such as Atlanta, Los Angeles, Chicago, and Washington, D.C. shifted from predominately white to majority Black or Brown (Sklansky 2006; Governing 2015; Forman 2017). As these seemingly antithetical identities collide, how do Black police officers navigate being both Black and blue?

I sought to examine the intersection of these identities in Atlanta, Georgia, a majority Black city that has been lauded for its leadership during the Civil Rights Movement and its longstanding tradition of Black leadership in all areas of local government (Hobson 2017). From August to December 2019, I conducted an ethnographic study of eleven African American police officers working in different police departments across the city. I sought to understand how they situate themselves between identities in relation to policing as violence through work. Being racially Black and professionally blue, these officers are caught in the middle as both agents of state violence against Black Americans and targets of the very same violence they enact.

Using a semistructured interview guide, I sat down with the officers at their offices, in different coffee shops, or in Chick-Fil-A locations around the city. On the days that the officers showed up in their uniforms, we received a few glares (which officers reported had become commonplace); however, some restaurants also gave them free meals to thank them for their service. One officer lamented that gestures like this had at one point been the norm. But, he said, as a result of the Black Lives Matter movement respect for officers has decreased as the public has grown increasingly critical of policing practices. He went on: 
When I first started, Black police officers were respected within the Black community. We were part of the community; we gave our people hope for better policing. They looked up to us, but that's no longer the case. Now we're seen as Uncle Toms or race traitors.

For a number of officers, the desire to be a positive influence defined their motivations for joining the force:

This is because growing up, a lot of us had negative experiences with the police. Growing up, I had been chased, pushed on the ground, and called a $\mathrm{N}^{*}$ by cops. I had no respect for them, and I believed they existed to work against our community. I thought by joining the force, I could change things from within.

So, the reason why I say Rodney King influenced my decision to join the force is because I felt that I could be that light, even in the African American community, to show them that one of your own is a police officer and we can be professional and fair.

Prior to joining the force, several officers had experienced individual and collective intergenerational trauma at the hands of police. These officers believed that, by joining the force, they could change it from within. It was going to be through diversity and inclusion that fair and just policing would be achieved. Their belief was that the more African American police officers there are, the better policing outcomes would be. This belief was predicated on the idea that it is the people who are the problem, not the system that they are a part of. For them, the institution of policing itself was not under interrogation, but rather the individual "bad apples," who could be replaced by Black officers. So how and why did their views fall out of sync with the broader community?

To understand this shift in perceptions of African American police officers, I had to understand the nature of police work itself. In their daily policing practices the African American police officers I got to know aimed to embody a spirit of professional and fair policing. They sought to challenge discriminatory practices, especially when carried out by fellow officers. They described not shying away from reprimanding other officers or speaking out against what they perceived as unfair stereotypes. However, their departments' measures of success did not always align with their personal values. In this sense, these officers struggled with being both Black and blue.

Fundamental to understanding these officers' struggles is W. E. B. Du Bois's (1897) and Frantz Fanon's (1967) conceptualizations of double consciousness as applied to race and professional identity. Du Bois theorized that African American police officers have to negotiate two historically distinct strivings, the striving to be "blue" and the striving to be "Black" - in one "dark body." Here, the labor of policing becomes a social process through which value is created. As individual futures of class mobility are imagined, the separation between the exceptional and the disposable widens. The mutually exclusive 
identities of Black and blue are reconciled through capitulation to blue logics. Blackness becomes a tool through which individual exceptionalism is deployed as a justification for racialized policing practices. Success within this framework requires the performance of symbolic blackness through diversity and inclusion hiring practices. Such practices promote a select few African Americans to middle-class status while simultaneously weaponizing their employment to continue oppressive practices in lowincome African American communities under the guise of post-civil rights, "colorblind" policing strategies (Alexander 2010).

Officers described their struggles with maintaining personal values in light of departmental expectations. One community officer recalled engaging in trust-building exercises by playing soccer with local children and otherwise enmeshing himself in the community he policed. But he recounted his horror when his department placed his image on their website, celebrating his contribution to a successful U.S. Immigration and Customs Enforcement (ICE) raid, which ran counter to the "Officer Friendly" image he was working to cultivate. This discordance between what represented departmental success (arrest stats, cooperation with other federal or local anticrime agencies) and local officers' efforts to build up community institutions served to highlight the difficulty they faced in their efforts to ascend through the ranks while simultaneously maintaining residents' trust. The nature of their work seemed antithetical to their efforts to pursue reform through increased representation.

Part of this balancing act was finding ways to appease African American and other minority communities while simultaneously practicing, promoting, and perpetuating practices that harmed them. Officers relied on respectability politics as a moral agentive tool deployed as a justification for practices that largely target African Americans (Alexander 2010; Mattingly 2014). They differentiated between racial profiling and criminal profiling by defining the former as indiscriminately targeting members of a particular racial group and the latter as targeting individuals who just did not "fit in." These individuals were said not to be limited to any racial category but were identifiable through their presence in a particular area, their clothing choices, and their behavior in a given situation. Through criminal profiling, the officers rationalized policing practices that end up directed at African Americans as largely individualized and based on suspicious behavior, without racial discrimination as their driving force. This distinction guides African Americans as they work within the system, separating themselves from their overpoliced brethren by negating the social value of those deemed moral failures (Mattingly 2014). This shift in perspective from "beacons of hope" to profilers of criminals leads to the reproduction of the same racialized logics that these officers had initially vowed to change.

I had the opportunity to witness these logics in action when one of my study participants invited me to a community forum where African American residents spoke to a group of police officers on ways to 
improve police-community relations. Although the police contingent was racially diverse, only African American officers spoke while white and Hispanic officers listened. During the forum, community members relayed harrowing narratives of negative police encounters. One young African American woman, who was no older than twenty-five, spoke of how her brother was murdered by the police in a Midwestern city, prompting her to flee the city and move to Atlanta. She communicated her gratitude to Atlanta officers for holding forums such as these, which encouraged dialogue between police and community members, even on uncomfortable topics. She then proceeded to ask how police worked to protect and serve the African American community in Atlanta. Although the officers were sympathetic to this young woman's loss, their responses to her puzzled me.

I slowly noticed that the discussion was not centered around the ways that police work to serve the community, but instead around how African American civilians can best behave to avoid negative police interactions. Residents were given specific advice: keep their hands on the wheel when pulled over, obey the commands of police officers, and follow all instructions until the encounter was over. This struck me as odd, since residents such as this young woman had related memories of firsthand experiences with police violence. The message from the officers was geared toward good citizen behavior; in other words, the expectation was placed on the citizen to prevent negative interactions. The strategic employment of respectability politics at this event highlighted, for me, an important shift in the African American police officers' perspectives. Many were the same officers who joined the force because they had been unjustly violated by police during their lives and had seen their service as a means to combat racialized police violence. Yet this forum laid bare the dominant attitudes of the force: it was community residents, not the police, who needed to learn how to behave. It was the individual suspect who does not "fit in" who had to modify themselves to fit prescribed notions of belonging.

Although African American police officers may have hopes for reforming the police, it became clear to me that once they became part of the system, they employed similar logics that gave rise to "bad apples." It is through criminal profiling that African American police officers are able to individualize and weaponize the rhetoric of respectability politics to perpetuate anti-Black logics (Bell 1992). This perspective does not bring a critical analysis to the institution of policing but instead turns scrutiny back on communities, whose residents are blamed for the resulting overpolicing. African American officers joined the force with the goal of reforming the ways their communities are policed. However, this study illustrates that increasing diversity without implementing structural change serves to reproduce the very forms of inequality that racial diversity in policing was intended to address. The capitulation of these African American officers to anti-Black logics of policing highlights an occupational transformation that these Black officers undergo, from serving the public to serving the institution. 


\section{Author Bio}

Tatenda Mangurenje (she/her) is a $\mathrm{PhD}$ candidate in the Department of Anthropology at Emory University.

\section{Preview Image}

Photo by Chris Henry.

\section{References}

Alexander, Michelle. 2010. The New Jim Crow: Mass Incarceration in the Age of Colorblindness. New York: The New Press.

Bell, Derrick. 1992. Faces at the Bottom of the Well: The Permanence of Racism. New York: Basic Books.

Du Bois, W. E. B. 1897. “Strivings of the Negro People." Atlantic, August.

Fanon, Frantz. 1967. Black Skin, White Masks: The Experiences of a Black Man in a White World. New York: Grove. Originally published in 1952.

Forman, Jr., James. 2017. Locking Up Our Own: Crime and Punishment in Black America. New York: Farrar, Straus and Giroux.

Governing. 2015. "Diversity on the Force: Where Police Don't Mirror Communities." Special report. Hall, Stuart. 1978. Policing the Crisis: Mugging, the State, and Law and Order. London: Macmillan. Hobson, Maurice J. 2017. The Legend of the Black Mecca: Politics and Class in the Making of Modern Atlanta. Chapel Hill: University of North Carolina Press.

Jackson, George. 1994. Soledad Brother: The Prison Letters of George Jackson. Chicago: Lawrence Hill.

Mattingly, Cheryl. 2014. Moral Laboratories: Family Peril and the Struggle for a Good Life. Oakland: University of California Press.

Rickford, Russell. 2015. “Black Lives Matter: Toward a Modern Practice of Mass Struggle." New Labor Forum 25(1): 34-42.

Ritskes, Eric. 2015. “The Fleshy Excess of Black Life: Mike Brown, Eric Garner, and Tamir Rice." Decolonization: Indigeneity, Education, and Society, January 2.

Shakur, Assata. 1987. Assata: An Autobiography. Chicago: Lawrence Hill. 
Sklansky, David Alan. 2006. “Not Your Father's Police Department: Making Sense of the New Demographics of Law Enforcement." Journal of Criminal Law and Criminology 96(3): 1209-1244. 